\title{
Structure of the upper teeth of the red fox (Vulpes vulpes) and Arctic fox (Vulpes lagopus) and analysis of dental variability in insular forms
}

\author{
Dmitriy O. Gimranov
}

\begin{abstract}
Various polymorphic dental characters of Vulpes vulpes and Vulpes lagopus have been described on the basis of a detailed description of the occlusal surfaces of P4, M1, and M2. The prevalence of these characters was found to be significantly different between samples of $V$. vulpes and mainland $V$. lagopus, which can be used to determine species in a fossil record. Notably, Commander Islands $V$. lagopus differ from mainland $V$. lagopus in most of the characters. However, some characters of Mednyi Island V. lagopus are unique to them and are not found in any other sample. Some samples from Bering Island do not display such specific features. Samples of ancient foxes, $V$. praeglacialis and $V$. praecorsac, have also been studied. Primitive features were observed in both $V$. praeglacialis and $V$. praecorsac, with the latter exhibiting also a number of advanced features. It has also been found that primitive features are prevalent in the maxillary dentition of $V$. vulpes. The insular groups of $V$. lagopus display numerous primitive features, whereas mainland $V$. lagopus demonstrate a substantial number of advanced characters. This combination of primitive and advanced features is typical of insular $V$. lagopus and indirectly suggests that these populations have spent a long time in isolation.
\end{abstract}

How to cite this article: Gimranov D.O. 2021. Structure of the upper teeth of the red fox (Vulpes vulpes) and Arctic fox (Vulpes lagopus) and analysis of dental variability in insular forms // Russian J. Theriol. Vol.20. No.1. P.96-110. doi: 10.15298/rusjtheriol.20.1.10.

KEY WORDS: Vulpes vulpes, Vulpes lagopus, upper teeth, variability, dental characters, insular isolation, diagnosis of species.

Dmitriy O. Gimranov [djulfa250@rambler.ru], Institute of Plant and Animal Ecology, Ural Branch of the Russian Academy of Sciences, 8 Marta str. 202, Yekaterinburg 620144, Russia.

\section{Структура верхних зубов лисицы (Vulpes vulpes) и песца (V. lagopus) и анализ ее изменчивости у островных форм}

\begin{abstract}
Д.О. Гимранов
РЕЗЮМЕ. На основе детального изучения коронарных поверхностей Р4, М1 и М2 описаны зубные признаки у $V$. vulpes и $V$. lagopus обладающие полиморфизмом. Частота встречаемости зубных признаков существенно различалась между $V$. vulpes и материковым V. lagopus. Это может быть использовано при идентификации ископаемых остатков этих близкородственных видов. Островные (Командорские) $V$. lagopus отличаются от материковых $V$. lagopus по многих признакам, в то время как некоторые особенности строения зубов $V$. lagopus с о. Медный уникальны для них и не встречаются в других выборках. У некоторых песцов с острова Беринга подобные особенности не прослеживаются. Для понимания эволюционного характера признаков исследовались зубы древних форм V. praeglacialis и $V$. praecorsac. Примитивные черты в строении зубов наблюдались как у $V$. praeglacialis, так и у $V$. praecorsac, но у последнего имеется и ряд продвинутых характеристик. Среди всех изученных современных выборок примитивные состояния зубных признаков преобладают у $V$. vulpes. Островные группы $V$. lagopus демонстрируют многочисленные примитивные особенности в строении зубов, в то время как материковые $V$. lagopus демонстрируют значительное число продвинутых состояний. Такое сочетание примитивных признаков с прогрессивными характерно для островных V. lagopus и косвенно свидетельствует о том, что эти популяции долгое время находятся в изоляции.
\end{abstract}

КЛЮЧЕВЫЕ СЛОВА: Vulpes vulpes, Vulpes lagopus, верхние зубы, изменчивость, зубные признаки, островная изоляция, диагностика видов. 


\section{Introduction}

Both the red fox (Vulpes vulpes L., 1758) and Arctic fox (Vulpes lagopus L., 1758) are widely spread species. $V$. vulpes are distributed throughout Northern Eurasia, except in tundra and Arctic zones, whereas $V$. lagopus mostly populate inland and Arctic island territories.

Besides overlapping in the past, the areas of these two species are currently overlapping (Aristov \& Baryshnikov, 2001). Remains of both $V$. vulpes and $V$. lagopus are commonly found in Pleistocene and Holocene faunas (Vereshchagin \& Kuzmina, 1982; Kuzmina \& Sablin, 1993; Sommer \& Benecke, 2004; Kosintsev et al., 2016). However, differentiating these two species on the basis of fossil isolated specimens is complicated (Benes, 1975; Lanoe, 2012). Generally, extensive variability is observed in the morphological structures of living and fossil members of the Canidae family. In particular, extensive variability has been observed in the dental morphology of members of the genus Vulpes (Szuma, 2007, 2011; Tedford et al., 2009; Perini et al., 2010; Prevosti, 2010; Gimranov et al., 2015; Gimranov, 2017; Szuma \& Germonpré, $2020 \mathrm{a}, \mathrm{b})$. Therefore, in many cases, some important dental characters cannot be used to describe a species or population without a preliminary study of their variability. Previous investigations have attempted to describe the variability of the dental morphology of the $V$. vulpes and $V$. lagopus using Eurasian collections of these species (Szuma, 2000, 2002, 2003, 2007, 2011; Gimranov et al., 2015; Gimranov, 2017). However, E. Szuma considered these variations only as a tendency to form either more complicated or more simplified morphotypes within a single character. Similar to other researchers who studied this topic (Gimranov et al., 2015; Gimranov, 2017), Szuma did not discuss the evolutionary nature of the variability of dental characters.

However, both authors provide us with quite extensive information on the variability of the upper cheek teeth of different members of the Vulpes genus (Szuma, 2002, 2007, 2011; Gimranov, 2017). Szuma $(2007,2011)$ proven that the $\mathrm{P} 4 \mathrm{~V}$. vulpes and V. lagopus were found to have variable lingual cingulum, protocone position and plesioconule, while M1 had variable lingual cingulum and hypocone. Gimranov (2017) also comes to this conclusion and complements it: in $\mathrm{P} 4$ the $V$. vulpes, $V$. corsac and $V$. lagopus are variable metacone of $\mathrm{P} 4$, with an occlusal shape and protocone complex in M1. Gimranov (2017) also evaluated the variability of M2 and highlighted the different morphotypes for this tooth.

Studying the morphological variability of recent $V$. vulpes and $V$. lagopus from Northern Eurasia, we found significant differentiation in the dental characters between mainland $V$. lagopus and Commander Islands V. lagopus (Gimranov, 2014). The presence of such differentiation in $V$. lagopus (exterior, dimensional, and genetic) has been frequently discussed by researchers (Heptner et al., 1967; Džikija et al., 2007; Geffen et al., 2007; Szuma, 2008, 2011; Ploshnitsa et al., 2012, 2013; Nanova \& Proa, 2017; Martín-Serra et al., 2019a; Proa
\& Nanova, 2019). The reasons for these differences are clearly related to the island specificity of these animals and their isolation from the mainland community. Studying the dental morphology and comparatively analyzing the dental characters of the members of the Vulpini tribe can provide us with an opportunity to analyze island forms in terms of island isolation.

Thus, the aims of this study are to describe the morphology of occlusal surfaces of the teeth of two Vulpes species ( $V$. vulpes and $V$. lagopus) and to evaluate the variation of the dental characters of Commander Islands $V$. lagopus populations from the viewpoint of the influence of island isolation.

\section{Materials and methods}

Cranial samples of $V$. vulpes and $V$. lagopus from different parts of Russia and other countries were studied. Data were obtained from collections of the Zoological Museum of Moscow State University (Moscow), Zoological Institute of the Russian Academy of Sciences (Saint Petersburg), and the Museum of the Institute of Plant and Animal Ecology (Yekaterinburg).

The localities and sample sizes for $V$. vulpes were as follows: Armenia $(n=10)$; Austria $(n=1)$; Azerbaijan $(n=3)$; Belarus $(n=12)$; Bulgaria $(n=1)$; Georgia $(n=$ 4); Germany $(n=6)$; Kazakhstan $(n=5)$; Kyrgyzstan $(n=3)$; Mongolia $(n=13)$; Romania $(n=5)$; Russia, Amur Region $(n=6)$, Arkhangelsk Region $(n=9)$, Astrakhan Region $(n=3)$, Volgograd Region $(n=5)$, Vologda Region $(n=9)$, Voronezh Region $(n=10)$, Irkutsk Region $(n=10)$, Kaliningrad Region $(n=5)$, Kamchatka Territory $(n=10)$, Kirov Region $(n=5)$, Krasnodar Territory $(n=16)$, Krasnoyarsk Territory $(n=$ 17), Leningrad Region ( $n=12)$, Magadan Region ( $n=$ 4), Moscow Region ( $n=6)$, Murmansk Region $(n=6)$, Novgorod Region $(n=2)$, Novosibirsk Region $(n=1)$, Orenburg Region $(n=12)$, Primorye Territory $(n=11)$, Pskov Region $(n=4)$, Republic of Altai $(n=6)$, Republic of Kalmykia $(n=4)$, Republic of Sakha (Yakutia, $n=15)$, Republic of Tatarstan $(n=6)$, Republic of Tuva $(n=5)$, Rostov Region $(n=5)$, Samara Region $(n=4)$, Saratov Region $(n=10)$, Smolensk Region $(n=8)$, Tver Region $(n=7)$, Tyumen Region $(n=2)$, Udmurt Republic $(n=$ $3)$, Khabarovsk Territory $(n=6)$, Chelyabinsk Region $(n=16)$, and Chukotka Autonomous Area $(n=12)$; Tajikistan $(n=5)$; Turkmenistan $(n=15)$; Ukraine $(n=$ $15)$; and Uzbekistan $(n=10)$.

The localities and sample sizes for $V$. lagopus were as follows: Norway $(n=12)$ and Russia, Arkhangelsk Region $(n=30)$, Kamchatka Territory (Bering Island, $n=30$; Mednyi Island, $n=13$ ), Krasnoyarsk Territory $(n=35)$, Republic of Sakha (Yakutia, $n=30)$, Chukotka Autonomous Area $(n=30)$, and Yamal-Nenets Autonomous Area $(n=12)$. Table 1 shows a list of the characters discussed in this study. The following published data was used to describe dental occlusal surfaces and determine the characters' grades (Butler, 1939; Hershkovitz, 1971; Tedford et al., 1995, 2009; 
Table 1. Description of the characters and states of the teeth.

\begin{tabular}{|c|c|c|c|c|}
\hline \multirow{28}{*}{ P4 } & Characters & & State & Description \\
\hline & \multirow{4}{*}{ Lingual cingulum } & & A & Complete \\
\hline & & & $\mathrm{B}$ & Incomplete \\
\hline & & & $\mathrm{C}$ & Present under the metacone blade \\
\hline & & & $\mathrm{D}$ & Absent \\
\hline & \multirow{4}{*}{ Cingulum around the protocone } & & $\mathrm{E}$ & Complete \\
\hline & & & $\mathrm{F}$ & Incomplete \\
\hline & & & $\mathrm{G}$ & Present only at the posterior part of the protocone \\
\hline & & & $\mathrm{H}$ & Absent \\
\hline & \multirow{6}{*}{ Protocone crests } & \multirow{2}{*}{ I } & \multirow{2}{*}{$\begin{array}{c}\text { Anterior } \\
\text { crest }\end{array}$} & Present \\
\hline & & & & Absent \\
\hline & & \multirow{2}{*}{$\mathrm{J}$} & \multirow{2}{*}{$\begin{array}{c}\text { Posterior } \\
\text { crest }\end{array}$} & Present \\
\hline & & & & Absent \\
\hline & & \multirow{2}{*}{$\mathrm{K}$} & \multirow{2}{*}{$\begin{array}{l}\text { Inner } \\
\text { crest }\end{array}$} & Present \\
\hline & & & & Absent \\
\hline & \multirow{4}{*}{ Anterior cingulum } & & $\mathrm{L}$ & Extends on the labial side of the crown \\
\hline & & & $\mathrm{M}$ & Extends to the anterolabial corner of the crown \\
\hline & & & $\mathrm{N}$ & Developed only on the anterior side \\
\hline & & & $\mathrm{O}$ & Developed only at the base of the anterior paracone crest \\
\hline & \multirow{3}{*}{ Lingual paracone crest } & & $\mathrm{P}$ & Rises from the base of the protocone to the top of the paracone \\
\hline & & & Q & Extends from of the protocone base to the paracone base \\
\hline & & & $\mathrm{R}$ & Absent \\
\hline & \multirow{2}{*}{ Parastyle } & & $\mathrm{S}$ & Present \\
\hline & & & $\mathrm{T}$ & Absent \\
\hline & \multirow{4}{*}{ Plesioconule } & & $\mathrm{U}$ & Very large \\
\hline & & & $\mathrm{V}$ & Medium size \\
\hline & & & $\mathrm{W}$ & Small \\
\hline & & & $\mathrm{X}$ & Absent \\
\hline \multirow{22}{*}{ M1 } & Lingual cingulum around the proto- & & $\mathrm{A}$ & Complete \\
\hline & cone & & $\mathrm{B}$ & Incomplete \\
\hline & & & $\mathrm{C}$ & Very large \\
\hline & Developed of the parastyle (Ps) & & $\mathrm{D}$ & Medium size \\
\hline & & & E & Small or absent \\
\hline & & & $\mathrm{F}$ & Cingulum complete, extends to the hypocone \\
\hline & Cingulum behind the metaconule & & G & Cingulum does not extend to the hypocone \\
\hline & & & $\mathrm{H}$ & Absent \\
\hline & & & $\mathrm{I}$ & Complete \\
\hline & Inner crest of the paracone & & $\mathrm{J}$ & Incomplete \\
\hline & & & $\mathrm{K}$ & Absent \\
\hline & Paraconule separation from the & & $\mathrm{L}$ & Present \\
\hline & preprotocrista & & $\mathrm{M}$ & Absent \\
\hline & & & $\mathrm{N}$ & Small \\
\hline & & & $\mathrm{O}$ & Large \\
\hline & Hypocone & & $\mathrm{P}$ & Large, divided into two parts by an inner groove \\
\hline & & & $\mathrm{Q}$ & Large, divided into three parts by inner grooves \\
\hline & & & $\mathrm{R}$ & Double-cusped \\
\hline & Inner crest of the hynocone & & $\mathrm{S}$ & Present \\
\hline & Inner crest or the nypocone & & $\mathrm{T}$ & Absent \\
\hline & Posterolingul cingulum & & $\mathrm{U}$ & No contact with metaconule \\
\hline & Posterolingual cinguium & & $\mathrm{V}$ & Contact with metaconule is present \\
\hline & & & A & Metacone length equal to paracone length \\
\hline & Metacone & & $\mathrm{B}$ & Metacone length is slightly smaller than paracone length \\
\hline & & & $\mathrm{C}$ & Metacone length half as less as paracone length \\
\hline & & & $\mathrm{D}$ & Complete, with a cusp-like metaconule \\
\hline & & & E & Complete, with a ridge-like metaconule \\
\hline & Postprotocrista & & $\mathrm{F}$ & Incomplete postprotocrista, with a reduced metaconule \\
\hline & & & $\mathrm{G}$ & Not developed \\
\hline $\mathbf{M 2}$ & Protocone & & $\mathrm{H}$ & Reduced \\
\hline & Lingual cingulum around & & $\mathrm{I}$ & Complete \\
\hline & the protocone & & $\mathrm{J}$ & Incomplete \\
\hline & & & $\mathrm{K}$ & Present \\
\hline & Protocone and paraconule separation & & $\mathrm{L}$ & Absent \\
\hline & & & $\mathrm{M}$ & Large \\
\hline & Hypocone & & $\mathrm{N}$ & Small \\
\hline
\end{tabular}


Rabeder, 1999). In particular, we noted that, in the Canidae family, the posterolingual cingulum of M1 and M2 is referred to as the hypocone (Wang et al., 1999; Tedford et al., 2009). In this study, we followed Tedford and Wang and used the term "hypocone."

None of the samples were categorized on the basis of sex, as previous research has shown that dental morphotype variation of the $V$. vulpes and $V$. lagopus is not significantly associated with sex (Szuma, 2002; El'kina, 2007). Only individuals with unworn teeth were included in the analysis, and individuals displaying different character states in the left and right teeth were excluded.

To define the relationships (primitive or derived) between the character states studied, we used the date matrices of the dental characters published by Wang (1994), Wang et al. (1999), Tedford et al. (1995, 2009), and Prevosti (2010). Table 1 shows a list of the studied characters and their states for P4 and M1-M2. The structure of the teeth of $V$. praeglacialis (Kormos, 1932) and $V$. praecorsac (Kormos, 1932) was discussed on the basis of published images and descriptions (Del Campana, 1913; Kormos, 1932; Thenius, 1954; Viret, 1954; Odintzov, 1965; Kurten, 1968; Bonifay, 1971; Rabeder, 1976; Kurtén \& Crusafont-Pairò, 1977; Jánossy, 1986; Wiszniowska, 1989; García \& Arsuaga, 1999; Caleros et al., 2006; Garrido, 2008; Madurell-Malapeira et al., 2009; Petrucci et al., 2013; Koufos, 2014, 2018; Rook et al., 2017). We also had the opportunity to study some of the collections listed above at the Hungarian Natural History Museum (five samples of $V$. praeglacialis from Early Pleistocene localities, Villány, Hungary), the Hungarian Institute of Geology and Geophysics (three samples of $V$. praeglacialis and two samples of V. praecorsac from Early Pleistocene localities, Villány, Hungary), and the Department of Palaeontology of the University of Vienna (15 samples of $V$. praeglacialis and five samples of $V$. praecorsac from Early Pleistocene localities, Deutsch Altenburg 2C, Austria).

Notably, Alopex (which is the same as V. lagopus) has been previously treated as a separate genus. However, at present, it is considered a subgenus of Vulpes (Wilson \& Reeder, 2005; Abramov \& Khlyap, 2012).

\section{Results}

P4 - In V. vulpes, the lingual cingulum (Fig. 1) is either completely developed $(48.9 \%$, state $\mathrm{A})$ or incompletely developed (44.2\%, state B; Tab. 2), whereas the lingual cingulum in mainland $V$. lagopus is strongly reduced $(40.9 \%$, state $\mathrm{C})$. In the island populations of $V$. lagopus, the completely developed form is predominant $(66.7 \%$ and $69.2 \%$, state A).

The lingual cingulum around the protocone is present only at the posterior part of the protocone in $V$. vulpes and mainland $V$. lagopus ( $81.8 \%$ and $96.2 \%$, state $G$ ), whereas in the islands forms of $V$. lagopus, the cingulum around the protocone is frequently less complete $(73.3 \%$ and $61.5 \%$, state $\mathrm{G}$ ).
The anterior protocone crest is absent (state I "absent") in both $V$. vulpes and mainland and Bering Island $V$. lagopus but quite prevalent in Mednyi Island $V$. lagopus (38.5\%, state I "present"). On the other hand, the posterior protocone crest is almost always present in $V$. vulpes (95.3\%, state $\mathrm{J}$ "present"). In mainland and Bering Island $V$. lagopus, this feature is observed in approximately half of the cases $(57 \%$ and $46.7 \%$, state $\mathrm{J}$ "present"). In Mednyi Island $V$. lagopus, this character is very frequent $(76.9 \%$, state $\mathrm{J}$ "present").

The inner protocone crest is almost ubiquitous in $V$. vulpes (93.4\%, state K "present") and completely fixed in the island populations of $V$. lagopus $(100 \%$ and $100 \%$, state K "present"). However, this character is often absent in mainland $V$. lagopus (22.6\%, state K "absent").

The anterior cingulum in $V$. vulpes is less developed $(17.4 \%$, states $\mathrm{L}$ and $\mathrm{M})$ than in the island populations of V. lagopus ( $96.7 \%$ and $61.5 \%$, states L and M). Mainland $V$. lagopus exhibit almost equal frequencies of developed (47.2\%, states L and M) and weakly developed (52.8\%, state $\mathrm{N}$ ) anterior cingulum.

The lingual paracone crest in $V$. vulpes is complete in the majority of the individuals $(94.2 \%$, state $\mathrm{P})$ but typically incomplete or absent in mainland $V$. lagopus $(46.5 \%$, state Q; $52.2 \%$, state R). This character is often absent in Bering Island V. lagopus $(76.7 \%$, state $\mathrm{R})$ but is totally absent in Mednyi Island $V$. lagopus $(100 \%$, state R).

The parastyle (Fig. 2) is usually absent (state T) in all species and forms studied (Tab. 2). The parastyle is very rarely present in mainland $V$. lagopus $(2.5 \%$, state $\mathrm{S})$ and Bering Island $V$. lagopus (3.3\%, state $\mathrm{S})$. The same holds true for the plesioconule (Fig. 2) in $V$. vulpes $(96.8 \%$, state $\mathrm{X})$ and Mednyi Island V. lagopus (100\%, state X). This character is occasionally found in a weakly pronounced form in mainland $(17.0 \%$, state $\mathrm{W})$ and Bering Island (26.7\%, state W) V. lagopus.

M1 - The lingual cingulum around the protocone (Tab. 3, Fig. 3) is often complete in $V$. vulpes $(70.0 \%$, state A) and the island populations of $V$. lagopus $(80 \%$ and $84.6 \%$, state A), whereas the incomplete variant of this character is predominant in mainland $V$. lagopus (66.7\%, state B).

The parastyle is small (state D) and mostly absent (state E) in almost all species and forms studied. The cingulum behind the metaconule is typically well developed in $V$. vulpes $(91.9 \%$, state $G)$ and the island populations of $V$. lagopus (70\% and $84.6 \%$, state $\mathrm{G})$ and is mainly absent in mainland $V$. lagopus $(91.2 \%$, state $\mathrm{H})$.

The inner crest of the paracone in $V$. vulpes is often complete and well developed $(98.9 \%$, state I), whereas the reduced variant (state $\mathrm{O}$ or $\mathrm{K}$ ) is predominant in all individuals of $V$. lagopus studied.

The separation of the paraconule from the preprotocrista was not studied in the island populations of $V$. lagopus. This character is frequent in $V$. vulpes (98.4\%, state L) and moderately prevalent in mainland V. lagopus $(50 \%$, state L).

In all species and forms studied, the hypocone is predominantly large and well developed (Fig. 4, state O). 


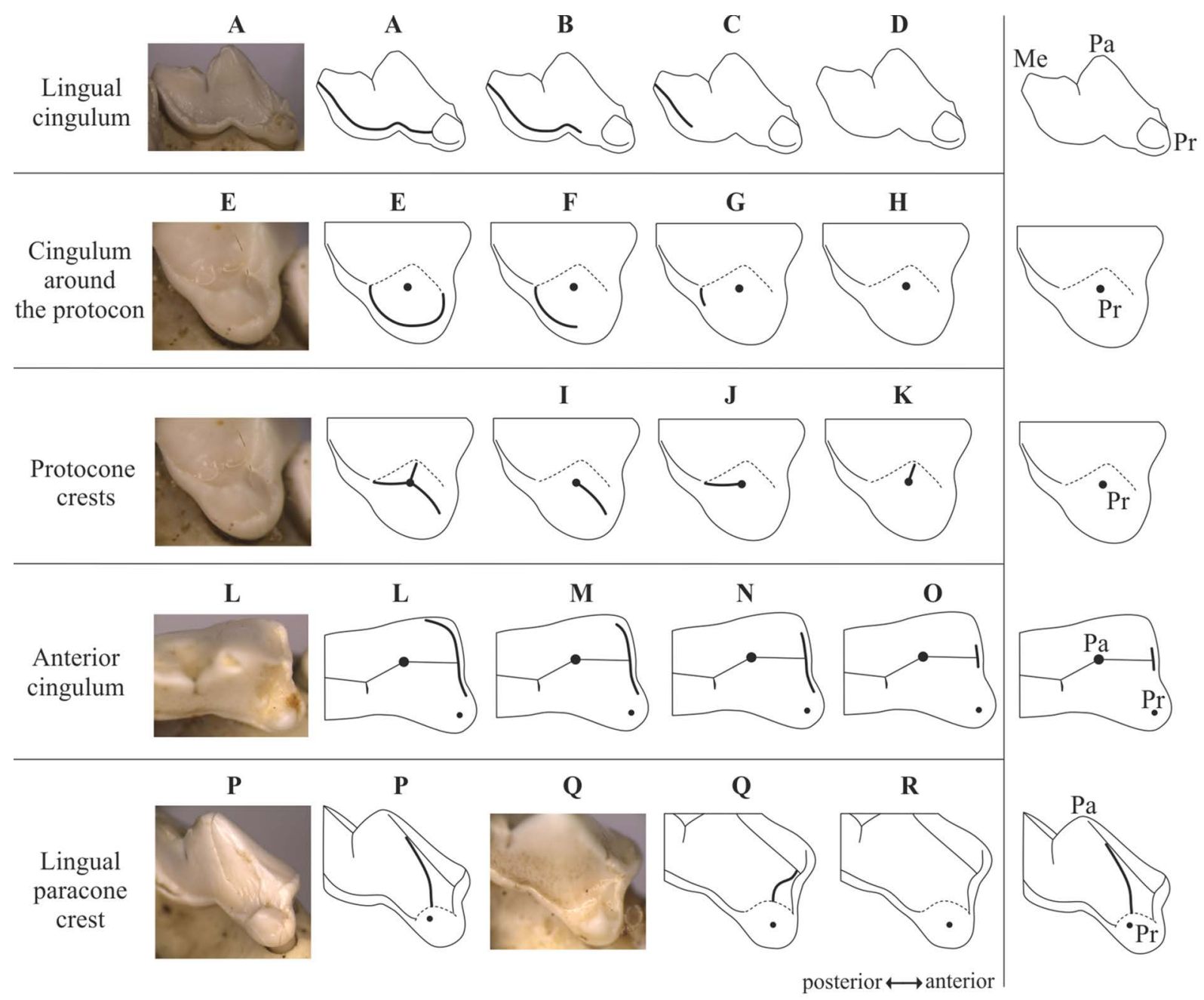

Fig. 1. States of the characters of the $\mathrm{P} 4$ in $V$. vulpes and V. lagopus. $\mathrm{Pa}-\mathrm{Paracone}, \mathrm{Me}$ - Metacone, $\mathrm{Pr}$ - Protocone. Lingual view: states $\mathrm{A}-\mathrm{D}$ and $\mathrm{P}-\mathrm{R}$, occlusal view: states $\mathrm{E}-\mathrm{O}$.

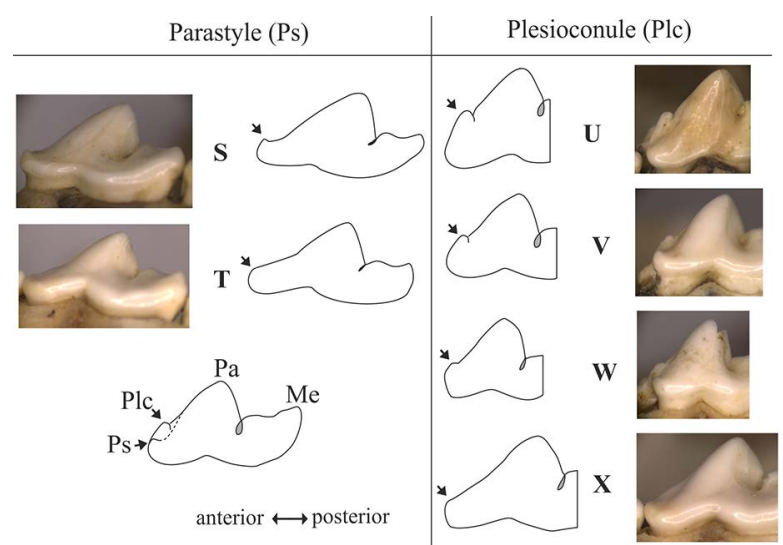

Fig. 2. States of the characters of the $\mathrm{P} 4$ in $V$. vulpes and V. lagopus. Pa — Paracone, Me — Metacone, Ps — Parastyle, Plc - plesioconule (labial view).

Notably, in $V$. vulpes, the cusp often displays an inner groove $(22.9 \%$, state $\mathrm{P})$.
The inner crest of the hypocone is frequently absent in the majority of $V$. vulpes (88.4\%, state T) and Bering Island $V$. lagopus $(93.9 \%$, state $\mathrm{T})$ specimens. In mainland and Mednyi Island $V$. lagopus, this character is also frequently absent ( $71.1 \%$ and $76.9 \%$, respectively).

The posterior cingulum of the hypocone is often not connected to the metaconule in $V$. vulpes $(98.9 \%$, state $\mathrm{U})$ and the insular populations of $V$. lagopus $(80.0 \%$ and $100 \%$, state U). However, in mainland $V$. lagopus, it merges with the metaconule in half of the cases $(54.4 \%$, state V).

M2 - In $V$. vulpes, the metacone length (Tab. 4, Fig. 5) is typically large, only slightly smaller than the paracone length $(75.1 \%$, state B). In mainland and Bering Island $V$. lagopus, the metacone length is frequently two times smaller than the paracone length $(73.9 \%$ and $70.0 \%$, state C), whereas in Mednyi Island $V$. lagopus, a large metacone is predominant $(46.2 \%$, state B). The metacone and paracone lengths in Mednyi Island $\mathrm{V}$. lagopus are most frequently equal (15.4\%, state A).

The postprotocrista in $V$. vulpes is often complete, with a ridge-like metaconule $(55.5 \%$, state E). In 
Table 2. Frequencies of the characters of the $\mathrm{P} 4$ in members of the genus Vulpes. $1-V$. vulpes (all), $2-V$. lagopus (mainland), $3-$ V. lagopus (Bering Island), $4-$ V. lagopus (Mednyi Island), $5-$ V. praeglacialis, $6-V$. praecorsac.

\begin{tabular}{|c|c|c|c|c|c|c|c|c|c|c|c|c|}
\hline \multirow{2}{*}{ Characters } & \multirow{2}{*}{\multicolumn{2}{|c|}{ State }} & \multicolumn{2}{|c|}{1} & \multicolumn{2}{|c|}{2} & \multicolumn{2}{|c|}{3} & \multicolumn{2}{|c|}{4} & \multirow{2}{*}{$\begin{array}{l}5 \\
n\end{array}$} & \multirow{2}{*}{$\frac{6}{n}$} \\
\hline & & & $\%$ & $n$ & $\%$ & $n$ & $\%$ & $n$ & $\%$ & $n$ & & \\
\hline \multirow{4}{*}{ Lingual cingulum } & & A & 185 & 48.9 & 17 & 10.7 & 20 & 66.7 & 9 & 69.2 & 19 & 7 \\
\hline & & $\mathrm{B}$ & 167 & 44.2 & 50 & 31.4 & 9 & 30.0 & 4 & 30.8 & 0 & 0 \\
\hline & & $\mathrm{C}$ & 26 & 6.9 & 65 & 40.9 & 1 & 3.3 & 0 & 0.0 & 0 & 0 \\
\hline & & $\mathrm{D}$ & 0 & 0.0 & 27 & 17.0 & 0 & 0.0 & 0 & 0.0 & 0 & 0 \\
\hline \multicolumn{3}{|l|}{$n$} & 378 & & 159 & & 30 & & 13 & & 19 & 7 \\
\hline \multirow{4}{*}{$\begin{array}{l}\text { Cingulum around } \\
\text { the protocone }\end{array}$} & & $\mathrm{E}$ & 32 & 8.4 & 1 & 0.6 & 3 & 10.0 & 0 & 0.0 & 0 & 0 \\
\hline & & $\mathrm{F}$ & 37 & 9.7 & 5 & 3.2 & 5 & 16.7 & 5 & 38.5 & 0 & 0 \\
\hline & & $\mathrm{G}$ & 311 & 81.8 & 151 & 96.2 & 22 & 73.3 & 8 & 61.5 & 2 & 0 \\
\hline & & $\mathrm{H}$ & 0 & 0.0 & 0 & 0 & 0 & 0.0 & 0 & 0.0 & 18 & 7 \\
\hline \multicolumn{3}{|l|}{$n$} & 380 & & 157 & & 30 & & 13 & & 20 & 7 \\
\hline \multirow{9}{*}{ Protocone crests } & \multirow{2}{*}{ I } & Present & 2 & 0.5 & 2 & 1.3 & 0 & 0.0 & 5 & 38.5 & 1 & 0 \\
\hline & & Absent & 378 & 99.5 & 157 & 98.7 & 30 & 100.0 & 8 & 61.5 & 17 & 7 \\
\hline & \multicolumn{2}{|l|}{$n$} & 380 & & 159 & & 30 & & 13 & & 18 & 7 \\
\hline & \multirow{2}{*}{$\mathrm{J}$} & Present & 362 & 95.3 & 90 & 57.0 & 14 & 46.7 & 10 & 76.9 & 18 & 7 \\
\hline & & Absent & 18 & 4.7 & 68 & 43.0 & 16 & 53.3 & 3 & 23.1 & 1 & 0 \\
\hline & \multicolumn{2}{|l|}{$n$} & 387 & & 158 & & 30 & & 13 & & 19 & 7 \\
\hline & \multirow{2}{*}{ K } & Present & 355 & 93.4 & 123 & 77.4 & 30 & 100.0 & 13 & 100.0 & 18 & 6 \\
\hline & & Absent & 25 & 6.6 & 36 & 22.6 & 0 & 0.0 & 0 & 0.0 & 2 & 1 \\
\hline & $n$ & & 387 & & 159 & & 30 & & 13 & & 20 & 7 \\
\hline \multirow{4}{*}{$\begin{array}{l}\text { Anterior } \\
\text { cingulum }\end{array}$} & & $\mathrm{L}$ & 0 & 0.0 & 2 & 1.3 & 0 & 0.0 & 0 & 0.0 & 11 & 2 \\
\hline & & $\mathrm{M}$ & 66 & 17.4 & 73 & 45.9 & 29 & 96.7 & 8 & 61.5 & 7 & 5 \\
\hline & & $\mathrm{N}$ & 283 & 74.7 & 84 & 52.8 & 1 & 3.3 & 5 & 38.5 & 2 & 0 \\
\hline & & $\mathrm{O}$ & 30 & 7.9 & 0 & 0.0 & 0 & 0.0 & 0 & 0.0 & 0 & 0 \\
\hline \multicolumn{3}{|l|}{$n$} & 379 & & 159 & & 30 & & 13 & & 20 & 7 \\
\hline \multirow{3}{*}{$\begin{array}{l}\text { Lingual } \\
\text { paracone crest }\end{array}$} & & $\mathrm{P}$ & 358 & 94.2 & 2 & 1.3 & 1 & 3.3 & 0 & 0.0 & 15 & 0 \\
\hline & & $\mathrm{Q}$ & 6 & 1.6 & 74 & 46.5 & 6 & 20.0 & 0 & 0.0 & 3 & 0 \\
\hline & & $\mathrm{R}$ & 16 & 4.2 & 83 & 52.2 & 23 & 76.7 & 13 & 100.0 & 2 & 7 \\
\hline \multicolumn{3}{|l|}{$n$} & 380 & & 159 & & 30 & & 13 & & 20 & 7 \\
\hline \multirow{2}{*}{ Parastyle } & & $\mathrm{S}$ & 0 & 0.0 & 4 & 2.5 & 1 & 3.3 & 0 & 0.0 & 1 & 2 \\
\hline & & $\mathrm{T}$ & 380 & 100.0 & 155 & 97.5 & 29 & 96.7 & 13 & 100.0 & 20 & 5 \\
\hline \multicolumn{3}{|l|}{$n$} & 380 & & 159 & & 30 & & 13 & & 21 & 7 \\
\hline & & $\mathrm{U}$ & 1 & 0.3 & 1 & 0.6 & 0 & 0.0 & 0 & 0.0 & 1 & 1 \\
\hline Plesioconule & & $\mathrm{V}$ & 6 & 1.6 & 4 & 2.5 & 0 & 0.0 & 0 & 0.0 & 3 & 1 \\
\hline PIesioconule & & $\mathrm{W}$ & 5 & 1.3 & 27 & 17.0 & 8 & 26.7 & 0 & 0.0 & 2 & 0 \\
\hline & & $X$ & 368 & 96.8 & 127 & 79.9 & 22 & 73.3 & 13 & 100.0 & 15 & 5 \\
\hline$n$ & & & 380 & & 159 & & 30 & & 13 & & 21 & 7 \\
\hline
\end{tabular}

mainland and Bering Island $V$. lagopus, absence of the metaconule is the main variant $(81.0 \%$ and $73.3 \%$, state G). Mednyi Island $V$. lagopus frequently display a particular (reduced) morphology of the protocone (76.9\%, state $\mathrm{H})$.

In $V$. vulpes, the lingual cingulum around the protocone is often complete $(84.7 \%$, state I), contrary to all V. lagopus samples (Tab. 4). Bering Island V. lagopus are considered an exception, as they display a high rate of well-developed lingual cingula around the protocone $(43.3 \%$, state I).
The separation of the paraconule from the preprotocrista was not studied in the island populations of $V$. lagopus. This character is typically absent in $V$. vulpes (92.4\%, state L) and mainland $V$. lagopus (91.7\%, state L).

The hypocone is large and well developed in most cases in all $V$. vulpes and $V$. lagopus samples (from $76.7 \%$ to $100 \%$, state $\mathrm{M}$ ). Notably, mainland and Bering Island V. lagopus frequently exhibit a reduced, small hypocone $(22.6 \%$ and $23.3 \%$, state $\mathrm{N})$. 


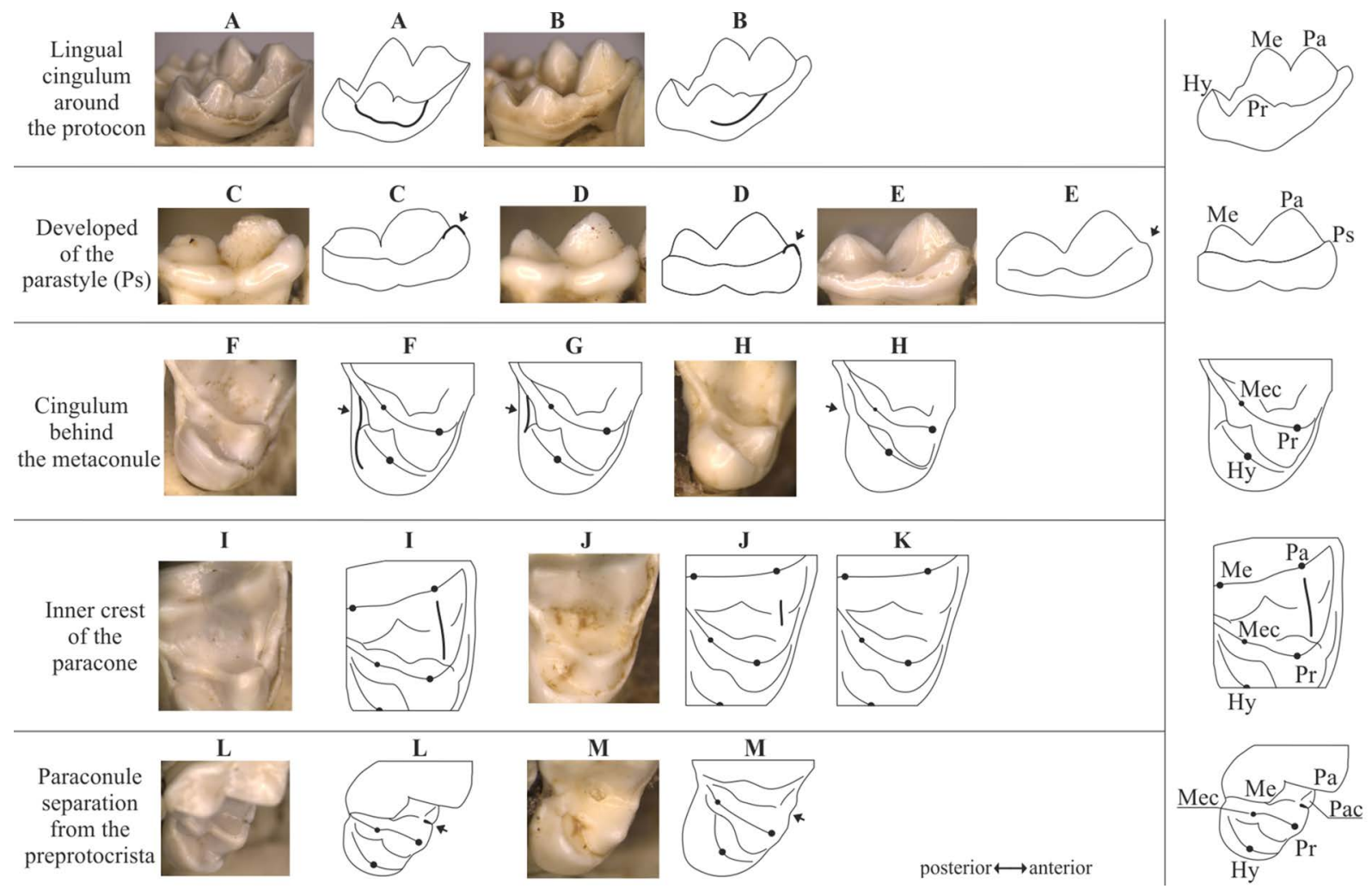

Fig. 3. Character and state of the $\mathrm{M} 1$ in $V$. vulpes and $V$. lagopus. $\mathrm{Pa}$ - Paracone, Me - Metacone, Pr - Protocone, Hy hypocone, Ps - Parastyle, Mec — metoconule, Pac — paraconule. Anterior view: state A-B, labial view: states C-E, occlusal view: states F-M.

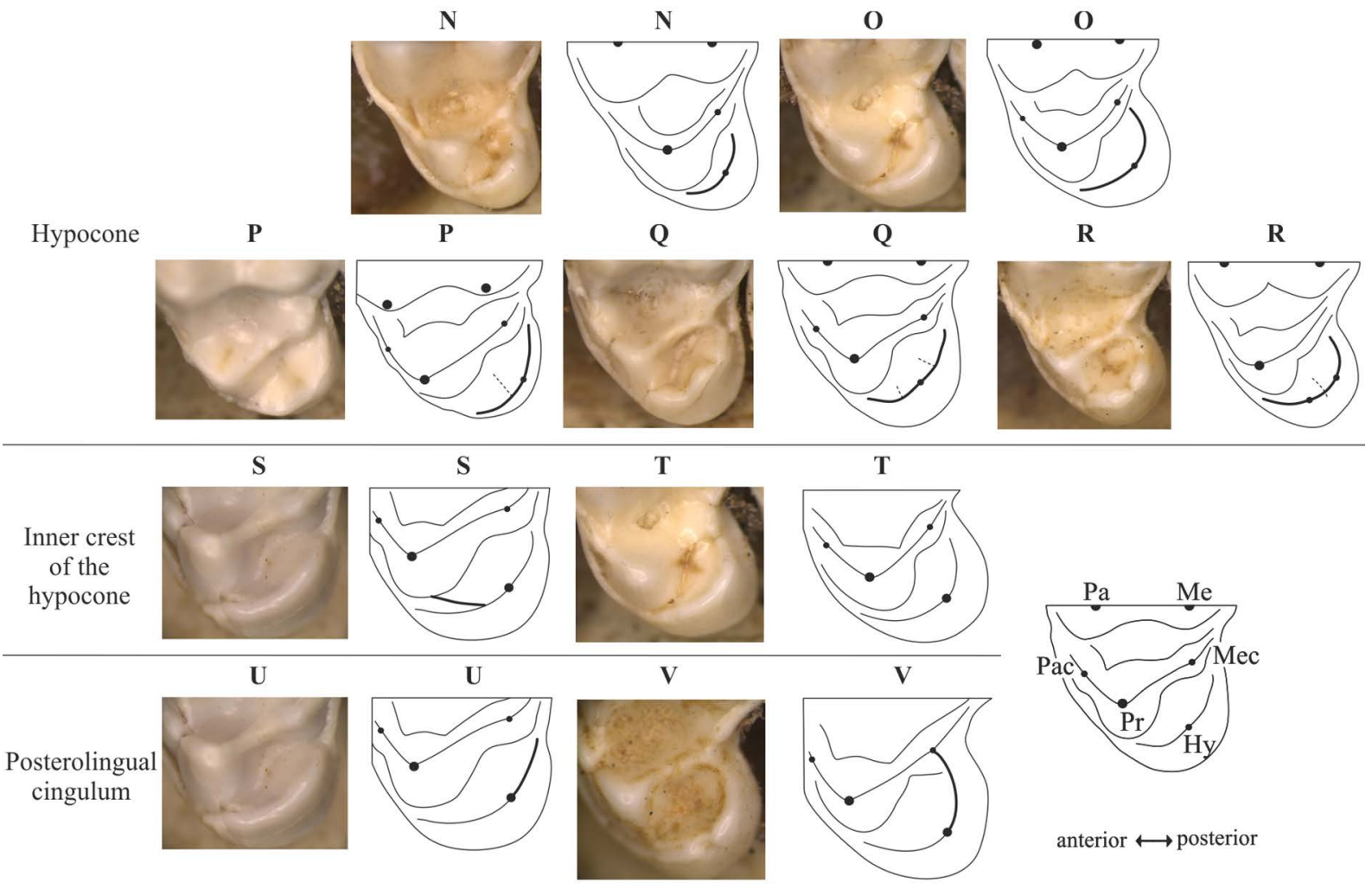

Fig. 4. Character and state of the M1 in $V$. vulpes and $V$. lagopus. Pa - Paracone, Me - Metacone, Pr - Protocone, Hy hypocone, Mec — metoconule, Pac — paraconule (occlusal view). 


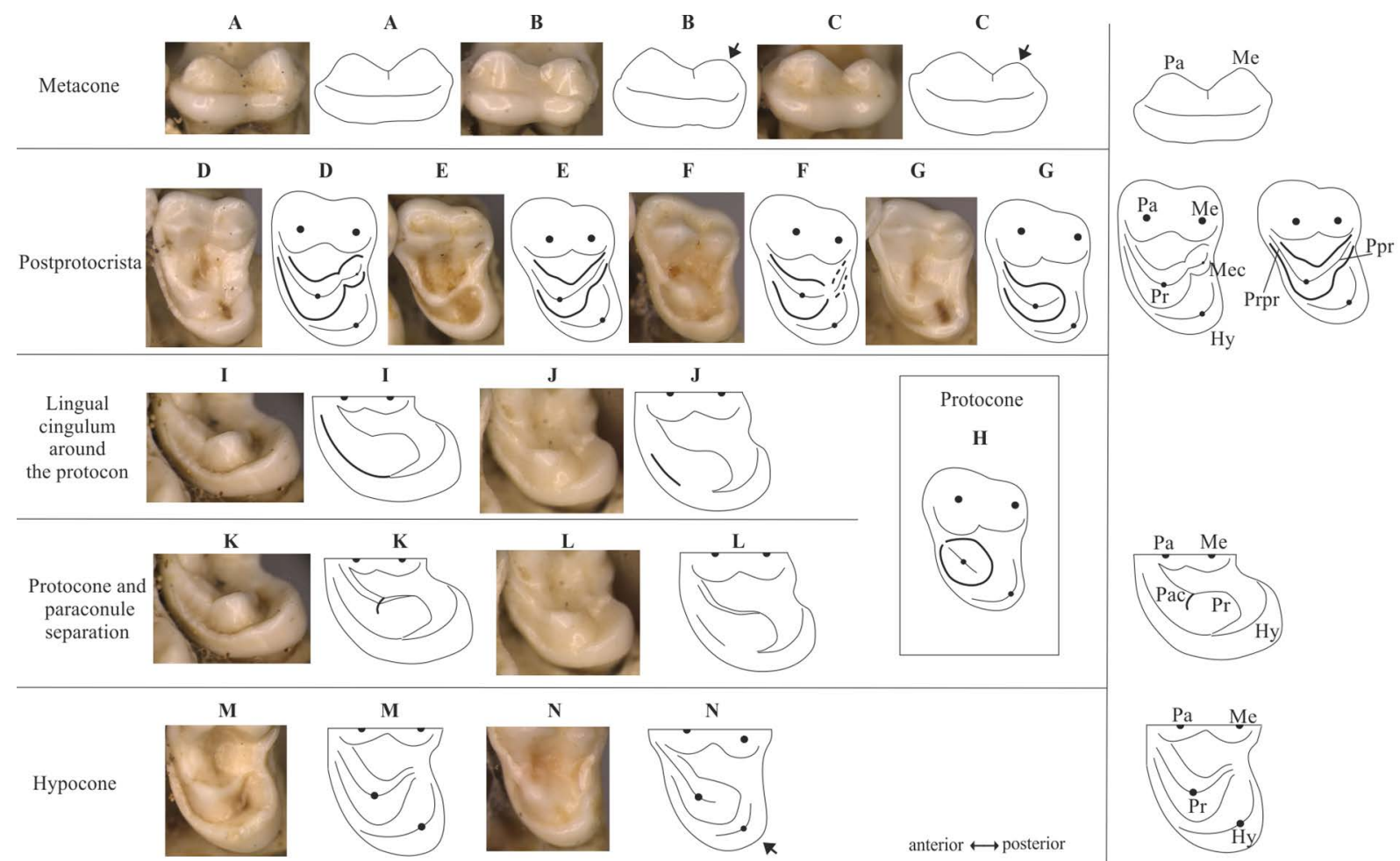

Fig. 5. Character and state of the $\mathrm{M} 2$ in $V$. vulpes and $V$. lagopus. $\mathrm{Pa}$ - Paracone, Me - Metacone, Pr — Protocone, Hy hypocone, Mec — metoconule, Pac — paraconule. Labial view: states A-C, occlusal view: states D-N.

\section{Discussion}

\section{Interspecific variability}

P4 - The results of this study show that $V$. vulpes can be distinguished from mainland $V$. lagopus on the basis of most of the characters studied. The most important characters for distinguishing between these two species are the lingual cingulum, posterior and inner protocone crests, development of the anterior cingulum, and shape of the lingual paracone crest of $\mathrm{P} 4$. The island samples of $V$. lagopus display a similarity to $V$. vulpes in terms of the morphology of the lingual cingulum and the crests of the protocone. The frequency of the anterior cingulum helps differentiate the island populations of $V$. lagopus from both $V$. vulpes and mainland $V$. lagopus. Mednyi Island $V$. lagopus were found to be the most particular population differing from all the other groups of Vulpes in terms of the morphology of the cingulum around the protocone, anterior protocone crest, and anterior cingulum of P4. The morphotype typical of the island populations of $V$. lagopus can be broadly outlined as follows: complete lingual and anterior cingula, tendency toward a high frequency of complete cingula around the protocone, and presence of all three protocone crests. Except for the well-developed anterior cingulum and the presence of the anterior protocone crest, all of these characters are typical of $V$. vulpes as well. The shape of the lingual paracone crest is probably a unique feature of $V$. vulpes, which is mostly absent in $V$. lagopus. As previously shown, the complete lingual cingulum is more dominant than the discontinuous lingual cingulum (grades G1 and G2; Szuma, 2007) in $V$. vulpes from Northern Eurasia. Further, it was demonstrated that complete lingual cingula (grade G1; Szuma, 2011) are more frequently found in mainland $V$. lagopus than discontinuous lingual cingula (grade G1; Szuma, 2011). Our results demonstrate that a more detailed consideration of the morphology of the lingual cingulum in $V$. vulpes and $V$. lagopus is important for distinguishing between the two species. Variants of the morphology of the plesioconule of P4 were also described for $V$. vulpes and V. lagopus (Szuma, 2007, 2011). In $V$. vulpes from Northern Eurasia, a simple morphology without a pronounced plesioconule (grade E1; Szuma, 2007 ) is predominant, an observation that is in good agreement with our data (Tab. 2). Variants of P4 with a pronounced plesioconule (grades E2 and Ex3; Szuma, 2011) are more commonly found in mainland $V$. lagopus, which is also in line with the results of the present study (Tab. 2). Although a variation of some characters of P4 in $V$. vulpes and $V$. lagopus has been described earlier (Gimranov, 2017), in our previous studies, we did not consider the plesioconule and parastyle separately. It is of note, however, that the parastyle is extremely uncommon in $V$. vulpes and V. lagopus from Northern Eurasia.

M1 - Mainland $V$. lagopus can be distinguished from $V$. vulpes on the basis of most characters of the upper first molar: a developed lingual cingulum around the protocone, a cingulum behind the metaconule, and 
Table 3. Frequencies of the characters of the $\mathrm{M} 1$ in members of the genus Vulpes. $1-V$. vulpes (all), $2-V$. lagopus (mainland), $3-V$. lagopus (Bering Island), $4-$ V. lagopus (Mednyi Island), 5 - V. praeglacialis, 6 - V. praecorsac.

\begin{tabular}{|c|c|c|c|c|c|c|c|c|c|c|c|}
\hline \multirow{2}{*}{ Characters } & \multirow{2}{*}{ State } & \multicolumn{2}{|c|}{1} & \multicolumn{2}{|c|}{2} & \multicolumn{2}{|c|}{3} & \multicolumn{2}{|c|}{4} & \multirow{2}{*}{$\begin{array}{l}5 \\
n\end{array}$} & \multirow{2}{*}{$\frac{6}{n}$} \\
\hline & & $n$ & $\%$ & $n$ & $\%$ & $n$ & $\%$ & $n$ & $\%$ & & \\
\hline \multirow{2}{*}{$\begin{array}{l}\text { Lingual cingulum around the } \\
\text { protocon }\end{array}$} & $\mathrm{A}$ & 266 & 70.0 & 53 & 33.3 & 24 & 80.0 & 11 & 84.6 & 8 & 1 \\
\hline & $\mathrm{B}$ & 114 & 30.0 & 106 & 66.7 & 6 & 20.0 & 2 & 15.4 & 2 & 4 \\
\hline \multicolumn{2}{|l|}{$n$} & 380 & & 159 & & 30 & & 13 & & 10 & 5 \\
\hline \multirow{3}{*}{ Developed of the parastyle (Ps) } & $\mathrm{C}$ & 1 & 0.3 & 1 & 0.6 & 0 & 0.0 & 0 & 0.0 & 1 & 1 \\
\hline & $\mathrm{D}$ & 46 & 12.1 & 6 & 3.8 & 2 & 6.7 & 1 & 7.7 & 8 & 4 \\
\hline & $\mathrm{E}$ & 333 & 87.6 & 152 & 95.6 & 28 & 93.3 & 12 & 92.3 & 1 & 0 \\
\hline \multicolumn{2}{|l|}{$n$} & 380 & & 159 & & 30 & & 13 & & 10 & 5 \\
\hline \multirow{3}{*}{ Cingulum behind the metaconule } & $\mathrm{F}$ & 18 & 4.7 & 0 & 0.0 & 0 & 0.0 & 0 & 0.0 & 0 & 0 \\
\hline & $\mathrm{G}$ & 349 & 91.9 & 14 & 8.8 & 21 & 70.0 & 11 & 84.6 & 7 & 3 \\
\hline & $\mathrm{H}$ & 13 & 3.4 & 145 & 91.2 & 9 & 30.0 & 2 & 15.4 & 3 & 2 \\
\hline \multicolumn{2}{|l|}{$n$} & 380 & & 159 & & 30 & & 13 & & 10 & 5 \\
\hline \multirow{3}{*}{ Inner crest of the paracone } & $\mathrm{I}$ & 376 & 98.9 & 2 & 1.3 & 0 & 0.0 & 0 & 0.0 & \multirow{2}{*}{10} & \multirow{2}{*}{5} \\
\hline & $\mathrm{J}$ & 1 & 0.3 & 128 & 80.5 & 30 & 100.0 & 13 & 100.0 & & \\
\hline & $\mathrm{K}$ & 3 & 0.8 & 29 & 18.2 & 0 & 0.0 & 0 & 0.0 & 0 & 0 \\
\hline \multicolumn{2}{|l|}{$n$} & 380 & & 159 & & 30 & & 13 & & 10 & 5 \\
\hline \multirow{2}{*}{$\begin{array}{l}\text { Paraconule separation } \\
\text { from the preprotocrista }\end{array}$} & $\mathrm{L}$ & 373 & 98.4 & 6 & 50.0 & - & - & - & - & 8 & 5 \\
\hline & $\mathrm{M}$ & 6 & 1.6 & 6 & 50.0 & - & - & - & - & 0 & 0 \\
\hline \multicolumn{2}{|l|}{$n$} & 379 & & 12 & & - & & - & & 8 & 5 \\
\hline \multirow{5}{*}{ Hypocone } & $\mathrm{N}$ & 0 & 0.0 & 1 & 0.7 & 0 & 0.0 & 0 & 0.0 & 0 & 2 \\
\hline & $\mathrm{O}$ & 281 & 73.9 & 138 & 90.2 & 29 & 96.7 & 12 & 92.3 & 6 & 3 \\
\hline & $\mathrm{P}$ & 87 & 22.9 & 11 & 7.2 & 0 & 0.0 & 1 & 7.7 & 2 & 0 \\
\hline & $\mathrm{Q}$ & 1 & 0.3 & 0 & 0.0 & 0 & 0.0 & 0 & 0.0 & 0 & 0 \\
\hline & $\mathrm{R}$ & 11 & 2.9 & 3 & 2.0 & 1 & 3.3 & 0 & 0.0 & 2 & 0 \\
\hline \multicolumn{2}{|l|}{$n$} & 380 & & 153 & & 30 & & 13 & & 10 & 5 \\
\hline \multirow{2}{*}{ Inner crest of the hypocone } & $\mathrm{S}$ & 44 & 11.6 & 46 & 28.9 & 2 & 6.7 & 3 & 23.1 & - & - \\
\hline & $\mathrm{T}$ & 335 & 88.4 & 113 & 71.1 & 28 & 93.3 & 10 & 76.9 & - & - \\
\hline \multicolumn{2}{|l|}{$n$} & 379 & & 159 & & 30 & & 13 & & - & - \\
\hline \multirow{2}{*}{ Posterolingual cingulum } & $\mathrm{U}$ & 376 & 98.9 & 72 & 45.6 & 24 & 80.0 & 13 & 100.0 & 9 & 5 \\
\hline & $\mathrm{V}$ & 4 & 1.1 & 86 & 54.4 & 6 & 20.0 & 0 & 0.0 & 1 & 0 \\
\hline \multicolumn{2}{|l|}{$n$} & 380 & & 158 & & 30 & & 13 & & 10 & 5 \\
\hline
\end{tabular}

separation of the paraconule from the preprotocrista. The island populations of $V$. lagopus exhibit a cingulum behind the metaconule and a posterolingual cingulum, similar to $V$. vulpes. The frequency of an incomplete inner crest of the paracone is similar between the island populations of $V$. lagopus and mainland $V$. lagopus. All samples are broadly similar in terms of the prevalence of the main variants of the hypocone and the inner crest of the hypocone. It has been shown previously that two morphological variants are prevalent in $V$. vulpes from Northern Eurasia: without separation by a groove (grade H1; Szuma, 2007) and with a fully developed protocone cingulum (grade I1; Szuma, 2007). Our results confirm those findings. Szuma also demonstrated that hypocones without groove separation (grade H1; Szuma, 2011) and with incomplete protocone cingula (grade I2; Szuma, 2011) are predominant in mainland $V$. lagopus. This is also in good agreement with the results of the present study. The variation of some characters of M1 in V. vulpes and V. lagopus described previously (Gimranov,
2017) can be elaborated on by the results obtained for the hypocone in this study.

M2 - According to the three characters of the second upper molar, it is possible to differentiate $V$. vulpes from mainland $V$. lagopus. The diagnostic characters are the size of the metacone, the morphology of the postprotocrista, and the development of the lingual cingulum around the protocone. Although the hypocone does not display significant differences between the species, it exhibits a reduction tendency in $V$. lagopus. The morphologies of the metacone and protocone complex are very similar between mainland and Bering Island $V$. lagopus. However, Mednyi Island $V$. lagopus appear to be closer to $V$. vulpes in terms of the metacone morphology and display a particularity in the shape of the protocone as state $\mathrm{H}$ (reduced protocone) is not found in any other sample. An opposite scenario was observed for the lingual cingulum around the protocone: Mednyi Island V. lagopus are similar to their mainland conspecifics, whereas Bering Island $V$. lagopus display a similarity to $V$. vulpes. 
Table 4. Frequencies of the characters of the $\mathrm{M} 2$ in members of the genus Vulpes. $1-V$. vulpes (all), 2 -V. lagopus (mainland), $3-$ V. lagopus (Bering Island), $4-$ V. lagopus (Mednyi Island), 5 - V. praeglacialis, 6 - V. praecorsac. ${ }^{*}$ — one specimen has a double hypocone.

\begin{tabular}{|c|c|c|c|c|c|c|c|c|c|c|c|}
\hline \multirow{2}{*}{ Characters } & \multirow{2}{*}{ State } & \multicolumn{2}{|c|}{1} & \multicolumn{2}{|c|}{2} & \multicolumn{2}{|c|}{3} & \multicolumn{2}{|r|}{4} & \multirow{2}{*}{$\frac{5}{n}$} & \multirow{2}{*}{$\frac{6}{n}$} \\
\hline & & $n$ & $\%$ & $n$ & $\%$ & $n$ & $\%$ & $n$ & $\%$ & & \\
\hline \multirow{3}{*}{ Metacone } & $\mathrm{A}$ & 8 & 2.1 & 1 & 0.6 & 0 & 0.0 & 2 & 15.4 & 0 & 0 \\
\hline & $\mathrm{B}$ & 284 & 75.1 & 40 & 25.5 & 9 & 30.0 & 6 & 46.2 & 6 & 1 \\
\hline & $\mathrm{C}$ & 86 & 22.8 & 116 & 73.9 & 21 & 70.0 & 5 & 38.5 & 0 & 0 \\
\hline \multicolumn{2}{|l|}{$n$} & 378 & & 157 & & 30 & & 13 & & 6 & 1 \\
\hline \multirow{5}{*}{ Postprotocrista } & $\mathrm{D}$ & 50 & 14.4 & 1 & 0.6 & 2 & 6.7 & 0 & 0.0 & 2 & 0 \\
\hline & $\mathrm{E}$ & 193 & 55.5 & 8 & 5.1 & 2 & 6.7 & 0 & 0.0 & 3 & 1 \\
\hline & $\mathrm{F}$ & 81 & 23.3 & 21 & 13.3 & 4 & 13.3 & 0 & 0.0 & 1 & 0 \\
\hline & $\mathrm{G}$ & 24 & 6.9 & 128 & 81.0 & 22 & 73.3 & 3 & 23.1 & 0 & 0 \\
\hline & $\mathrm{H}$ & 0 & 0.0 & 0 & 0.0 & 0 & 0.0 & 10 & 76.9 & 0 & 0 \\
\hline \multicolumn{2}{|l|}{$n$} & 348 & & 158 & & 30 & & 13 & & 6 & 1 \\
\hline \multirow{2}{*}{$\begin{array}{l}\text { Lingual cingulum } \\
\text { around the protocon }\end{array}$} & I & 320 & 84.7 & 16 & 10.1 & 13 & 43.3 & 2 & 15.4 & 6 & 1 \\
\hline & $\mathrm{J}$ & 58 & 15.3 & 143 & 89.9 & 17 & 56.7 & 11 & 84.6 & 0 & 0 \\
\hline \multicolumn{2}{|l|}{$n$} & 378 & & 159 & & 30 & & 13 & & 6 & 1 \\
\hline \multirow{2}{*}{$\begin{array}{l}\text { Protocone and } \\
\text { paraconule separation }\end{array}$} & $\mathrm{K}$ & 29 & 7.6 & 1 & 8.3 & - & - & - & - & - & - \\
\hline & $\mathrm{L}$ & 351 & 92.4 & 11 & 91.7 & - & - & - & - & - & - \\
\hline \multicolumn{2}{|l|}{$n$} & 380 & & 12 & & - & & - & & - & - \\
\hline \multirow{2}{*}{ Hypocone } & $\mathrm{M}$ & 357 & 94.4 & 123 & 77.4 & 23 & 76.7 & 13 & 100.0 & $6^{*}$ & 0 \\
\hline & $\mathrm{N}$ & 21 & 5.6 & 36 & 22.6 & 7 & 23.3 & 0 & 0.0 & 0 & 1 \\
\hline \multicolumn{2}{|l|}{$n$} & 378 & & 159 & & 30 & & 13 & & 6 & 1 \\
\hline
\end{tabular}

Evolutionary interpretation of the results

The following are the earliest members of the genus Vulpes described from the Pliocene in Eurasia: V. praecorsac from Ukraine (Odintzov, 1965), V. qiuzhudingi from the Tibetan Plateau (Wang et al., 2014), and V. beihaiensis from China (Qiu \& Tedford, 1990).

Four species were described from the Early Pleistocene in Europe: V. alopecoides (Forsyth Major, 1875; Del Campana, 1913; Viret, 1954; Kurtén \& Crusafont-Pairò, 1977; Garrido, 2008; Petrucci et al., 2013; Koufos, 2014), V. praeglacialis (Kormos, 1932; Bonifay, 1971; Rabeder, 1976; Jánossy, 1986; García \& Arsuaga, 1999; Moigne et al., 2006; MadurellMalapeira et al., 2009; Koufos, 2018), V. praecorsac (Kormos, 1932; Jánossy, 1986; Rabeder, 1976; Gasparik \& Pazonyi, 2018), and $V$. angustidens (Thenius, 1954).

Many of the abovementioned authors thought that $V$. alopecoides, V. praeglacialis, and V. praecorsac are direct ancestors of $V$. vulpes and $V$. lagopus. However, according to other data, the ancestor of V. lagopus inhabited Asia in the Early Pliocene (Wang et al., 2014).

Recently, a new paper by Lucenti and MadurellMalapeira (2020) on ancient foxes was published. In that study, the authors combined all the findings on foxes from the Pleistocene in Europe into one species, $V$. alopecoides (Del Campana, 1913). However, we believe that it is important to leave the division between $V$. praeglacialis and $V$. praecorsac in this paper.
P4 - The primitive state of P4 in the Canidae family includes a developed anterior cingulum (Tedford et al., 2009) and the absence of the parastyle (Wang et al., 1999). On the other hand, the advanced state of P4 manifests as a reduction or absence of the anterior cingulum and presence of the parastyle and plesioconule.

In our opinion, the presence of a developed lingual cingulum in $\mathrm{P} 4$ is a primitive feature of Vulpini (Tab. 2). This conclusion is also based on the fact that the lingual cingulum is fairly developed in $V$. praeglacialis and $V$. praecorsac, fossil members of the genus Vulpes. Those fossil species lack a cingulum around the protocone, an anterior protocone crest, a parastyle, and a plesioconule and exhibit inner and posterior protocone crests and, finally, a fairly developed anterior cingulum of P4 (Kormos, 1932; Rabeder, 1976). Such a combination is predominant in modern $V$. vulpes and not typical of mainland $V$. lagopus. Notably, $V$. praeglacialis exhibit a fairly developed lingual paracone crest, which is rather absent in $V$. praecorsac and $V$. lagopus. This indicates that $V$. praeglacialis and $V$. praecorsac are different species.

We, hence, conclude that $V$. vulpes display numerous primitive morphological features in $\mathrm{P} 4$ and that mainland $V$. lagopus appear to be advanced in most characters. As previously mentioned, the island populations of $V$. lagopus tend to be morphologically similar to $V$. vulpes, meaning that Bering Island and Mednyi Island $V$. lagopus retained a primitive morphological state of 
P4. This observation indirectly suggests their long-term isolation from mainland populations.

M1 - The primitive complex of M1 in the Canidae family includes a developed parastyle and a well-developed protocone cingulum, as well as the presence of a paraconule and metaconule in the protocone crest and also the presence of a developed hypocone. The advanced state of the tooth is marked by an enlargement or reduction in the hypocone, an enlargement (to the size of the protocone) or reduction (slight) in the para- and metaconules, a substantial reduction in the parastyle, and an enlargement of the paracone with respect to the metacone (Tedford et al., 1995, 2009). In our opinion, the primitive state in Vulpini includes the presence of differentiated para- and metaconules of moderate size. This observation is supported by data on the morphology of M1 in the possible ancestral species, $V$. praeglacialis and $V$. praecorsac (Tab. 3). Both exhibit a small but fairly pronounced parastyle, a paraconule separated from the preprotocrista, and a posterolingual cingulum that does not merge with the metaconule. However, the development of the protocone and metaconule cingula differs between $V$. praeglacialis and $V$. praecorsac. In $V$. praeglacialis, the cingulum is complete and developed, whereas in V. praecorsac, the protocone cingulum is commonly incomplete and the metaconule cingulum is often absent (Kormos, 1932; Rabeder, 1976). Notably, the morphology of the hypocone differs between $V$. praeglacialis and $V$. praecorsac as well. The former predominately exhibit a developed hypocone and accessory elements (grooves) in the hypocone in some cases, whereas the latter display a developed hypocone as well but a reduced hypocone, without accessory elements in both cases. In both $V$. praeglacialis and $V$. praecorsac, we found a well-pronounced metaconule and a paraconule separated from the preprotocrista (morphotypes B2 and C2; Gimranov, 2017). The dental features of $V$. praeglacialis are generally more primitive. Interestingly, contrary to that, $V$. praecorsac already acquired a number of advanced characters: reduction or absence of the protocone and metaconule cingula and reduction of the hypocone.

Hence, we conclude that $V$. vulpes display numerous primitive morphological features in M1, namely, complete protocone and metaconule cingula, paraconule separation from the preprotocrista, and a posterolingual cingulum that does not merge with the metaconule. On the contrary, mainland $V$. lagopus display a number of advanced characters. Notably, the primitive morphology of the parastyle (fairly large) is extremely rare in all the recent samples. The island populations of $V$. lagopus are similar to $V$. vulpes in six characters and to mainland $V$. lagopus in only four characters of M1. The similarity between the island populations of $V$. lagopus and $V$. vulpes suggests that the former retained many primitive features of dental morphology.

M2 - The evolutionary transformations of M2 in the Canidae family are broadly similar to those of M1 The primitive state includes the presence and development of the parastyle, paraconule, and metaconule, as well as a developed protocone crest and hypocone. The advanced morphology of M2 is marked by a reduction in the hypocone and parastyle, a lesser development of the para- and metaconules, and a reduction in the protocone crest (Tedford et al., 1995, 2009). The protocone complex and protocone cingulum are similar between $V$. praeglacialis and $V$. praecorsac, with both morphological elements being fairly developed in those species. In ancient species, the metacone is slightly smaller than the paracone (Tab. 4). The difference between the two species is the presence of a developed hypocone in $V$. praeglacialis and the reduction of this cusp in V. praecorsac (Kormos, 1932; Rabeder, 1976). As no parastyle was detected in the specimens of recent Vulpes, this character was not discussed further.

We, hence, conclude that $V$. vulpes display numerous primitive morphological features in M2: The metacone is slightly smaller than the paracone, and the protocone complex, protocone cingulum, and hypocone are well developed. Mainland $V$. lagopus, on the other hand, display numerous advanced features, including a combination of characters opposite to those of $V$. vulpes. Notably, the insular morphs of $V$. lagopus are not as similar to $V$. vulpes in terms of M2 morphology as it was observed for P4 and M1. Only two characters, the large metacone and large hypocone, display a similarity between $V$. vulpes and $V$. lagopus from Mednyi Island. Mainland and Bering Island $V$. lagopus exhibit a tendency toward a reduction in the hypocone. The latter are similar to an extent to $V$. vulpes in terms of the protocone cingulum morphology and to mainland $V$. lagopus in terms of the protocone morphology. The shape of the protocone in Mednyi Island $V$. lagopus is peculiar and unique from that observed in other studied groups. In general, a remarkable combination of primitive and advanced features exists in the dentition of the island populations of $V$. lagopus complemented by features unique to these populations.

Both North American and Northern Eurasian $V$. lagopus are fairly homogenous genetically and display a low level of genetic differentiation (Dalen et al., 2005; Carmichael et al., 2007). Molecular data also suggest that Commander Islands $V$. lagopus strongly differ genetically from mainland populations (Geffen et al., 2007; Džikija, 2008). The results of morphological studies on recent $V$. lagopus corroborate the findings of molecular genetics (Puzachenko \& Zagrebelny, 2008; Szuma, 2008, 2011; Nanova, 2015; Nanova et al., 2017; Nanova \& Proa, 2017; Martín-Serra et al., 2019b). A previous study on the nonmetric characters of maxillary teeth (Gimranov, 2014) showed that Mednyi Island $V$. lagopus populations are clearly distinct from other modern groups of the same species. Szuma (2011) demonstrated that Commander Islands $V$. lagopus, according to the prevalence of different dental morphotypes, are very similar to $V$. vulpes and occupy the same branch of the Euclidean distance tree. The results of this study confirm the particularity and isolated position of the island populations of $V$. lagopus with respect to the mainland populations of this species. The dentition of the island groups represents 
a mixture of primitive, advanced, and unique features. One explanation for this phenomenon is the possible bottleneck event that might have taken place either as a result of long-term isolation on the islands or during the initial settlement of the islands at the turn of the Holocene (Goltsman et al., 2005; Džikija, 2008; Nanova et al., 2017; Proa \& Nanova, 2019). Another potential factor that could have led to a change in dentition might be the narrow range of food resources available on the islands. In our opinion, the modern dental pattern of $V$. lagopus from the Commander Islands is a result of the interplay of a complex of factors, including both factors mentioned above. One unquestionable observation, however, is that contact with mainland polar fox populations was lost a long time ago, when mainland $V$. lagopus still had many primitive features in their upper dentition. We assume that the island populations of $V$. lagopus stopped coming into contact with mainland $V$. lagopus at the end of the Late Pleistocene.

\section{Conclusion}

Our detailed description of the occlusal surfaces of $\mathrm{P} 4, \mathrm{M} 1$, and $\mathrm{M} 2$ revealed a number of polymorphic dental characters, some of which are typical of $V$. vulpes while others are typical of $V$. lagopus (nine characters for $\mathrm{P} 4$, eight characters for $\mathrm{M} 1$, and five characters for M2). The frequency of the characters is significantly different between $V$. vulpes and mainland $V$. lagopus, and thus these characters can be used to distinguish between species.

It was observed that the island populations of $V$. lagopus differ from mainland $V$. lagopus in most of the characters. Mednyi Island $V$. lagopus are the most specific group as they display a number of unique dental features not found in other populations. However, this is not the case for Bering Island $V$. lagopus.

Primitive features of $\mathrm{P} 4, \mathrm{M} 1$, and $\mathrm{M} 2$ are found in both $V$. praeglacialis and $V$. praecorsac. However, the latter also exhibit a number of advanced features, indicating that $V$. praeglacialis and $V$. praecorsac are different species. Primitive features are also prevalent in the maxillary dentition of $V$. vulpes. Although the same applies to the island populations of $V$. lagopus, their mainland conspecifics display numerous advanced features. It can be concluded that the island populations inherited the primitive features from their mainland ancestors in the past. However, to understand the population history of the island populations of $V$. lagopus, it is important to understand the fact that they have retained these primitive features in combination with many advanced ones and also acquired some unique derived characters. This observation indirectly suggests the long-term isolation of the island populations of $V$. lagopus. However, the exact time of the last contact between them and the ancestral mainland populations can only be determined after studying Pleistocene $V$. lagopus.
ACKNOWLEDGMENTS. The author would like to thank M. Gasparik (Hungarian Natural History Museum, Hungary), M. Laszlo (Hungarian Institute of Geology and Geophysics, Hungary), G. Rabeder (Department of Palaeontology University of Vienna, Austria), G.F. Baryshnikov, M.V. Sablin and E.A. Petrova (Zoological Institute RAS, Russia), V.S. Lebedev, S.V. Kruskop and N.N. Spasskaya (Zoological Museum of the Moscow State University, Russia), N.G. Erokhin and T.P. Kourova (Museum of the Institute of Plant and Animal Ecology RAS, Russia) for giving access to the museum collections. The study was funded by RFBR (research project No. 16-19-04-00111-a) and by the Russian Government. The author would like to thank O.G. Nanova for collegial support. The author thanks A.A. Evteev for the help in preparation of the English version of this article and expresses his gratitude to P.A. Kosintsev for insightful discussion of draft versions of the manuscript. M.V. Sotnikova (Institute of Geology RAS, Moscow, Russia) made a very big contribution to this article, for which the author is sincerely grateful.

\section{References}

Abramov A.V. \& Khlyap L.A. 2012. Order Carnivora // Pavlinov I.Ya. \& Lissovsky A.A. (eds.). The Mammals of Russia: a Taxonomic and Geographic Reference. Moscow: KMK Scientific Press. P.313-382.

Aristov A.A. \& Baryshnikov G.F. 2001. [Mammals of Russia and Adjacent Territories. Carnivores and Pinnipeds]. Saint Petersburg: Zoological Institute RAS. 560 p. [in Russian].

Benes J. 1975. The Wurmian foxes of Bohemian and Moravian karst // Acta Musei Nationalis Pragae. Vol.31. P.149-209.

Bonifay M.F. 1971. Carnivores Quaternaires du Sud-Est de la France // Mémoires du Muséum National d'Histoire Naturelle. Vol.21. P.43-377.

Butler P.M. 1939. Studies of the mammalian dentition. Differentiation of the postcanine dentition // Proceedings of the Zoological Society of London. Vol.109. P.1-36.

Caleros J.A.C., Montoya P., Mancheño M.A. \& Morales J. 2006 Presencia de Vulpes praeglacialis (Kormos, 1932) en el yacimiento pleistoceno de la Sierra de Quibas (Abanilla, Murcia) // Estudios Geológicos. Vol.62. No.1. P.395-400.

Carmichael L.E., Krizan J., Nagy J.A., Fuglei E., Dumond M., Johnson D., Veitch A., Berteaux D. \& Strobeck C. 2007. Historical and ecological determinants of genetic structure in Arctic canids // Molecular Ecology. Vol.16. P.3466-3483.

Dalen L., Fuglei E., Hersteinsson P., Kapel C.M.O., Roth J.D., Samelius G., Tannerfeldt M. \& Angerbjörn A. 2005. Population history and genetic structure of a circumpolar species: the Arctic fox // Biological Journal of the Linnean Society. Vol.84. P.79-89.

Del Campana D. 1913. I cani Pliocenici di Toscana // Palaeontographica Italica. Vol.19. P.189-254.

Džikija E.L. 2008. [Genetic polymorphism of Commander Islands' Arctic foxes (Alopex lagopus semenovi Ognev, 1931, Alopex lagopus beringensis Merriam, 1902)]. 
Abstract of PhD Dissertation. Moscow: Moscow State University. 26 p. [in Russian].

Džikija E.L., Kolesnikov A.A., Chudakova D.A., Zagrebelny S. \& Goltsman M.E. 2007. [Genetic polymorphism of Commander Islands' Arctic foxes (Alopex lagopus semenovi Ognev, 1931, Alopex lagopus bering Merriam, 1902)] // Genetika. Vol.9. P.1239-1245 [in Russian].

El'kina M.A. 2007. [Morphotypic analysis of predatory teeth (P4 and m1) of Arctic fox (Alopex lagopus, Canidae, Carnivora) from the late Paleolithic sites Avdeevo and Sungir] // Rozanov A.Yu., Lopatin A.V. \& Parkhayev P. Yu. (eds.). [Modern Paleontology: Classical and Newest Methods]. Moscow: PIN RAS. P.73-80 [in Russian].

Forsyth Major C.I. 1875. Considerazioni sulla fauna dei mammiferi pliocenici e post pliocenici della Toscana // Atti della Società Toscana di Scienze Naturali. Vol.1. P.7-40.

García N. \& Arsuaga J.L. 1999. Carnivores from the Early Pleistocene hominid - bearing Trinchera Dolina 6 (Sierra de Atapuerca, Spain) // Journal of Human Evolution. Vol.37. P.415-430.

Garrido G. 2008. El registro de Vulpes alopecoides (ForsythMajor, 1877), Canis etruscus Forsyth-Major, 1877 y Canis cf. falconeri Forsyth-Major, 1877 (Canidae, Carnivora, Mammalia) en Fonelas P-1 (Cuenca de Guadix, Granada) // Arribas A. (ed.). Vertebrados del Plioceno Superior terminal en el suroeste de Europa: Fonelas P-1 y el proyecto Fonelas. Cuadernos del Museo Geominero. No.10. P.159-186.

Gasparik M. \& Pazonyi P. 2018. The macromammal remains and revised faunal list of the Somssich Hill 2 locality (late Early Pleistocene, Hungary) and the Epivillafranchian faunal change // Fragmenta Palaeontologica Hungarica. Vol.35. P.153-178.

Geffen E., Waidyaratne S., Dalén L., Angerbjörn A., Vila C., Hersteinsson P., Fuglei E., White P.A., Goltsman M., Kapel C.M.O. \& Wayne R.K. 2007. Sea ice occurrence predicts genetic isolation in the Arctic fox // Molecular Ecology. Vol.16. P.4241-4255.

Gimranov D.O. 2014. [Morphotypic variability of Arctic fox teeth (Vulpes lagopus L., 1758) from sites of the late Paleolithic Russian Plain] // Antonova E.V. et al. (eds.). [Ecology: Population, Species, Environment]. Proceedings of the Conference of Young Scientists. Yekaterinburg: Goschitsky. P.17-25 [in Russian].

Gimranov D.O. 2017. [Species diagnostics of the corsac (Vulpes corsac), fox (Vulpes vulpes) and Arctic fox (Vulpes lagopus, Carnivora, Canidae) using the upper teeth] // Zoologicheskii Zhurnal. Vol.96. No.6. P.684-697 [in Russian, with English summary].

Gimranov D.O., Kosintsev P.A. \& Gasilin V.V. 2015. [Specific diagnostics of the corsac (Vulpes corsac), fox (Vulpes vulpes) and Arctic fox (Vulpes lagopus) with dental features of teeth of the mandibulae] // Zoologicheskii Zhurnal. Vol.94. No.11. P.1338-1350 [in Russian, with English summary].

Goltsman M., Kruchenkova E.P., Sergeev S., Volodin I. \& Macdonald D.W. 2005. "Island syndrome" in a population of Arctic foxes (Alopex lagopus) from Mednyi Island // Journal of Zoology. Vol.267. P.405-418.
Jánossy D. 1986. Pleistocene vertebrate faunas of Hungary // Developments in Palaeontology and Stratigraphy. Vol.8. P.1-208.

Heptner V.G., Naumov N.P., Jurgenson P.B., Sludskii A.A., Chirkova A.F. \& Bannikov A.G. 1967. [Mammals of the USSR. Sea Cows and Carnivores]. Vol.2. Part 1. Moscow: Vysshaya Shkola. 1003 p. [in Russian].

Hershkovitz P. 1971. Basic crown patterns and cusp homologies of mammalian teeth // Dahlberg A.A. (ed.). Dental Morphology and Evolution. Chicago: University of Chicago Press. P.95-150.

Koufos G.D. 2014. The Villafranchian carnivoran guild of Greece: implications for the fauna, biochronology and paleoecology // Integrative Zoology. Vol.9. P.444-460.

Koufos G.D. 2018. New material and revision of the Carnivora, Mammalia from the Lower Pleistocene locality Apollonia 1, Greece // Quaternary. Vol.1. No.1. P.1-38.

Kormos T. 1932. Die Füchse des ungarischen Uberpliozäns // Folia Zoologica et Hydrobiologica. Vol.4. P.167-188.

Kosintsev P.A., Gasilin V.V., Gimranov D.O. \& Bachura O.P. 2016. Carnivores (Mammalia, Carnivora) of the Urals in the Late Pleistocene // Quaternary International. Vol.420. P.145-155.

Kurten B. 1968. Pleistocene Mammals of Europe. Chicago: Aldine Publishing. 320 p.

Kurten B. \& Crusafont-Pairó M. 1977. Villafranchian carnivores (Mammalia) from La Puebla de Valverde (Teruel, Spain) // Commentationes Biologicae. Vol.85. P.1-39.

Kuzmina I.E. \& Sablin M.V. 1993. [Arctic foxes of the Late Pleistocene from the Upper Desna] // Proceedings of the Zoological Institute RAS. Vol.249. P.93-104 [in Russian].

Lanoe F.B. 2012. Identification of Vulpes corsac (L., 1768) within upper Pleistocene assemblages: osteometric data and morphologic key of the dentition // Bulletin de la Société Préhistorique Française. Vol.109. P.331-334.

Lucenti S.B. \& Madurell-Malapeira J. 2020. Unraveling the fossil record of foxes: an updated review on the Plio-Pleistocene Vulpes spp. from Europe // Quaternary Science Reviews. Vol.236. e106296.

Madurell-Malapeira J., Alba D.M. \& Moyà-Solà S. 2009. Carnivora from the late early Pleistocene of Cal Guardiola (Terrassa, Vallès-Penedès Basin, Catalonia, Spain) // Journal of Paleontology. Vol.83. P.969-974.

Martín-Serra A., Nanova O.G., Ortega G., Varón-González C. \& Figueirido B. 2019a. Geographical isolation drives developmental modularity shifts in the skull of a critically endangered carnivore, the Arctic fox (Vulpes lagopus) // Journal of Morphology. Vol.280. P.S174.

Martín-Serra A., Nanova O., Varón-González C., Ortega G. \& Figueirido B. 2019b. Phenotypic integration and modularity drives skull shape divergence in the Arctic fox (Vulpes lagopus) from the Commander Islands // Biology Letters. Vol.15. No.9. P.20190406.

Moigne A.M., Palombo M.R., Belda V., Heriech-Briki D., Kacimi S., Lacombat F., Lumley M.A., Moutoussamy J., Rivals F., Quilès J. \& Testu A. 2006. Les faunes de grands mammifères de la Caune de l'Arago (Tautavel) dans le cadre biochronologique des faunes du Pléistocène moyen Italien // L'anthropologie. Vol.110. No.5. P.788-831. 
Nanova O.G. 2015. Morphological variation and integration of dentition in the Arctic fox (Vulpes lagopus): effects of island isolation // Russian Journal of Theriology. Vol.14. No.2. P.153-162.

Nanova O. \& Proa M. 2017. Cranial features of mainland and Commander Islands Arctic foxes Vulpes lagopus reflect their diverging foraging strategies // Polar Research. Vol.36. No.1. P.E68-E72.

Nanova O.G., Proa M., Fitton L., Evteev A.A. \& O’Higgins P. 2017. Comparison of cranial performance between mainland and two island subspecies of the Arctic fox Vulpes lagopus (Carnivora: Canidae) during simulated biting // Biological Journal of the Linnean Society. Vol.120. No.4. P.923-935.

Odintzov I.A. 1965. Vulpes praecorsac Kormos from Pliocene deposits of Odessa // Paleontologicheskii Sbornik. Vol.2. No.2. P.57-64 [in Russian with English summary].

Perini F.A., Russo C.A.M. \& Schrago C.G. 2010. The evolution of South American endemic canids: a history of rapid diversification and morphological parallelism // Journal of Evolutionary Biology. Vol.23. P.311-322.

Petrucci M., Cipullo A., Martínez-Navarro B., Rook L. \& Sardella R. 2013. The late Villafranchian (Early Pleistocene) carnivores (Carnivora, Mammalia) from Pirro Nord (Italy) // Palaeontographica Abteilung A: Paläozoologie-Stratigraphie. Vol.298. P.113-145.

Ploshnitsa A.I., Goltsman M.E., Macdonald D.W., Kennedy L.J. \& Sommer S. 2012. Impact of historical founder effects and a recent bottleneck on MHC variability in Commander Arctic foxes (Vulpes lagopus) // Ecology and Evolution. Vol.2. P.165-180.

Ploshnitsa A.I., Goltsman M.E., Happ G.M., Macdonald D.W. \& Kennedy L.J. 2013. Historical and modern neutral genetic variability in Mednyi Arctic foxes passed through a severe bottleneck // Journal of Zoology. Vol.289. P.68-76.

Prevosti F.J. 2010. Phylogeny of the large extinct South American canids (Mammalia, Carnivora, Canidae) using a "total evidence" approach // Cladistics. Vol.26. P.456-481.

Proa M. \& Nanova O. 2019. Severe population bottleneck in the 1970s caused cranial morphology to change in Mednyi Island subspecies of Arctic fox // Mammalia. Vol.84. No.2. P.162-170.

Puzachenko A.Y. \& Zagrebelny S.V. 2008. Variability of skull in polar fox (Alopex lagopus, Carnivora, Canidae) from Eurasia // Zoologicheskii Zhurnal. Vol.85. No.8. P.1007-1023 [in Russian, with English summary].

Qiu Z.\& Tedford R.H. 1990. A Pliocene species of Vulpes from Yushe, Shanxi // Vertebrata PalAsiatica. Vol.28. P.245-258.

Rabeder G. 1976. Die Carnivoren (Mammalia) aus dem Altpleistozän von Deutsch-Altenburg 2, mit Beiträgen zur Systematik einiger Musteliden und Caniden // Beiträge zur Paläontologie Österreich. Vol.1. P.5-119.

Rabeder G. 1999. Die Evolution des Höhlenbärengebisses // Mitteilungen der Kommission für Quartärforschung. Vol.11. P.1-102.

Rook L., Bartolini Lucenti S., Bukhsianidze M. \& Lordkipanidze D. 2017. The Kvabebi Canidae record revisited (Late Pliocene, Sighnaghi, Eastern Georgia) // Journal of Paleontology. Vol.91. No.6. P.1258-1271.
Sommer R. \& Benecke N. 2004. Late-Pleistocene and early Holocene history of the canid fauna of Europe (Canidae) // Mammalian Biology. Vol.70. No.4. P.227-241.

Szuma E. 2000. Dental polymorphism in a population of the red fox (Vulpes vulpes) from Poland // Journal of Zoology. Vol.256. P.243-253.

Szuma E. 2002. Variation and correlation patterns in the dentition of the red fox from Poland // Annales Zoologici Fennici. Vol.37. P.113-127.

Szuma E. 2003. Microevolutionary trends in the dentition of the red fox (Vulpes vulpes) // Journal of Zoological Systematics and Evolutionary Research. Vol.41. P.47-56.

Szuma E. 2007. Geography of dental polymorphism in red fox Vulpes vulpes and its evolutionary implications // Biological Journal of the Linnean Society. Vol.90. P.61-84.

Szuma E. 2008. Evolutionary and climatic factors affecting tooth size in the red fox Vulpes vulpes in the Holarctic // Acta Theriologica. Vol.53. P.289-332.

Szuma E. 2011. Ecological and evolutionary determinants of dental polymorphism in the Arctic fox Vulpes (Alopex) lagopus // Annales Zoologici Fennici. Vol.48. P.191-213.

Szuma E. \& Germonpré M. 2020a. Size of the lower carnassial in the Arctic and the red fox from Late Pleistocene in Belgium compared to other ancient and extant populations // Mammal Research. Vol.65. P.127-139.

Szuma E. \& Germonpré M. 2020b. Were ancient foxes far more carnivorous than recent ones? - Carnassial morphological evidence // PLoS ONE. Vol.15. e0227001.

Tedford R.H., Taylor B.E. \& Wang X. 1995. Phylogeny of the Caninae (Carnivora: Canidae): the living taxa // American Museum Novitates. Vol.3146. P.1-37.

Tedford R.H., Wang X. \& Taylor B.E. 2009. Phylogenetic systematics of the North American fossil Caninae (Carnivora: Canidae) // Bulletin of the American Museum of Natural History. Vol.325. P.1-218.

Thenius E. 1954. Die Caniden (Mammalia) aus dem Altquartär von Hundsheim (Niederösterreich) nebst Bemerkungen zur Stammesgeschichte der Gattung Cuon // Neues Jahrbuch für Geologie und Paläontologie. Vol.99. P.230-286.

Wang X. 1994. Phylogenetic systematics of the Hesperocyoninae (Carnivora, Canidae) // Bulletin of the American Museum of Natural History. Vol.221. P.1-207.

Wang X., Tedford R.H. \& Taylor B.E. 1999. Phylogenetic systematics of the Borophaginae (Carnivora, Canidae) // Bulletin of the American Museum of Natural History. Vol.243. P.1-391.

Wang X., Tseng Z.J., Li Q., Takeuchi G.T. \& Xie G. 2014. From 'third pole' to north pole: a Himalayan origin for the Arctic fox // Proceedings of the Royal Society B: Biological Sciences. Vol.281. P.1-7.

Wilson D.E. \& Reeder D.M. 2005. Mammal Species of the World: a Taxonomic and Geographic Reference. Third edition. Baltimore: Johns Hopkins University Press. $2142 \mathrm{p}$.

Wiszniowska T. 1989. Middle Pleistocene Carnivora (Mammalia) from Kozi Grzbiet in the Swietokrzyskie Mts Poland // Acta Zoologica Cracoviensia. Vol.32. P.589-630. 
Vereshchagin N.K. \& Kuzmina I.E. 1982. [Fauna of Mammals] // Praslov N.D. \& Rogochev A.N. (eds.). [Paleolithic of the Kostenki-Borshevo Area on the River Don. 1879-1979. Results of Field Investigations]. Leningrad: Nauka. P.223-232 [in Russian].
Viret J. 1954. Le lœss à bancs durcis de Saint-Vallier (Drôme) et sa faune de mammifères villafranchiens // Nouvelles Archives du Muséum d'Histoire Naturelle de Lyon. Vol.4. P.3-200. 